\title{
Economic and Environmental Impact of National Food Security Act of India
}

\author{
Priyam Sengupta ${ }^{1}$ and Kakali Mukhopadhyay ${ }^{2^{*}}$
}

\author{
* Correspondence: \\ kakali.mukhopadhyay@mcgill.ca \\ ${ }^{2}$ Department of Natural Resource \\ Sciences, Agricultural Economics \\ Program, McGill University, \\ Macdonald Campus, 21,111 \\ Lakeshore Road, Ste Anne de \\ Bellevue, Montreal, Quebec H9X3V9, \\ Canada \\ Full list of author information is \\ available at the end of the article
}

\begin{abstract}
The Government of India has enacted the National Food Security Act (NFSA) on September 12, 2013. The NFSA aims to provide subsidized food grains to approximately two thirds of India's population. The legislation is a landmark, and perhaps the largest food security program in the world. The ambitious programme of the Government, besides offering several opportunities, throws many challenges in its implementation. In this background, the current paper evaluates the widespread impact of implementing NFSA on the Indian economy. The study applied a modified Leontief and Ghosh model under Input-output framework. The study also assessed the environmental impact of this act focusing on various environmental indicators. Further, the additional land requirement, labour generation and GDP growth that NFSA entails have also been computed. The impacts on sectoral prices have also been calculated. The result shows that the food grain sector has to grow by $3.75 \%$ annually to match provision of food grains according to the norm set by the act. Apart from the targeted food grains sector, we noticed some indirect impact on other sectors such as Chemicals and Chemical Products, Mineral Fuels, Live stock products and Other Oilseeds and Crops. Overall the country needs to gear up in terms of food grain productivity, otherwise, NFSA must be supplemented by import, which would entail huge burden to country's exchequer. On the other hand, the additional GDP and labour growth is expected to generate $1.51 \%$ and $6.21 \%$ respectively due to NFSA compared to 2016-17. But the impact on the environment is also not favourable. The economy is likely to generate additional GHG emissions of 10.39 million metric tonne of $\mathrm{CO} 2$ equivalent due to this act. A significant generation of water pollution is also expected. The overall land requirement on account of NFSA has been found to be sizeable whose availability remains as a big constraint. The study also throws some insight on the achievements of The Millennium Development Goals in the context of NFSA. In the context of Indian sub-continent, we find a perfect synergy between the basic objective of National Food Security Act and Millennium Development Goal. Overall, NFSA impact will enhance the growth of the economy. However, additional pressure on environment and land cannot be ignored. For sustainable food grains production in the economy, the nation should consider the improvement of agriculture productivity as well as to minimize the environmental effect by introducing more sustainable farming practice.
\end{abstract}

\section{Background}

Food is the first among many basic human needs, and it is for this reason that "the human right to food is recognised in several instruments under international law (UN

\section{Springer}

(C) 2016 Sengupta and Mukhopadhyay. Open Access This article is distributed under the terms of the Creative Commons Attribution 4.0 International License (http://creativecommons.org/licenses/by/4.0/), which permits unrestricted use, distribution, and reproduction in any medium, provided you give appropriate credit to the original author(s) and the source, provide a link to the Creative Commons license, and indicate if changes were made. 
1999)." Food security is said to exist when all people, at all times, have physical, social and economic access to sufficient, safe and nutritious food that meets their dietary needs and food preferences for an active and healthy life (FAO 2009). Specifically, Article 11 of the International Covenant on Economic, Social and Cultural Rights recognises "the fundamental right to freedom from hunger and malnutrition (ibid.)."

The most disturbing feature of the Indian economy before last General Election (May 2014) has been the spiraling food grain prices. Ministry of Finance, Government of India along with Reserve Bank of India (RBI) was constantly trying to tame the inflationary pressure through various monetary measures but their success has been very limited. The situation worsened by the incidence of high poverty rate in the country. India is the second most populous country in the world with an estimated 1.2 billion people and the third largest economy by GDP. Thanks to steady economic growth over the past decade, India was classified as a (lower) middle-income country by the World Bank in 2012. An estimated $32.7 \%$ of the Indian population lives on less than US\$ 1.25 per day while $68.7 \%$ on less than US\$ 2 per day (World Bank 2010). According to a different estimate made by erstwhile Planning Commission (2013a, b, c), Government of India, total $21.92 \%$ population still lied below the poverty line (as delineated by Government of India). The country is home to a quarter of all undernourished people worldwide. India ranks 135th out of 187 countries in the 2014 UNDP Human Development Index and 55th out of 76 countries in the Global Hunger Index (WFP 2015). Any further increase in food grain prices would push the poor people to even more vulnerable situation.

Considering the fact that India has crossed 67 years after Independence, the situation is really a matter of grave concern and requires immediate attention. The Key priorities of the Government of India under the current Five-Year-Plan (2012-2017) are ensuring 'Faster, more Inclusive and Sustainable Growth'. This includes improving the performance of agriculture and diversifying produce as well as reducing vulnerabilities of small and marginal farmers with special focus on women and other disadvantaged groups. It also includes improving targeting, cost efficiency and nutrition effectiveness of the nationwide food-based social safety nets, namely the Targeted Public Distribution System $\left(\right.$ TPDS $\left.^{1}\right)$, the Integrated Child Development Service (ICDS), which is targeting mothers and young children and the Mid-Day-Meal Scheme (MDM). The targeted public distribution system (TPDS) and the mid-day meal scheme (approximately 120 million children are signed up) are two large government food distribution schemes in India. The misuse of resources and mismanagement of the programme was widespread and became well known. Problems of misappropriation of these programmes continue and the government is unable to achieve its goals. As a result of the inefficiencies of operations and entrepreneurial inabilities, majority of beneficiaries of the resources invested by the government are not the target population. Towards that end, second UPA government in India had introduced the National Food Security Bill, (also Right to Food Bill) in mid 2013. Subsequently, the National Food Security Bill (NFSB) was passed by both the houses of Parliament. The bill was signed into law on September 12, 2013. The intent of the National Food Security Bill was spelled out clearly in the Lok Sabha Committee Report, which stated, "Food security means availability of sufficient food grains to meet the domestic demand as well as access, at the individual level, to adequate quantities of food at affordable prices." The report added, "The proposed 
legislation marks a paradigm shift in addressing the problem of food security-from the current welfare approach to a right based approach". NFSB aimed to provide subsidized food grains to approximately two thirds of India's population under Targeted Public Distribution System (TPDS). The legislation was a landmark, and perhaps the largest food security program in the world.

The new bill had categorised the citizens of India into three clear groups based on their income levels (GOI 2013). Group-I comprised of the poorest section of people who earned only subsistence income. Economic condition of this group was just marginal. Under the provisions of the bill, beneficiaries under Group-I were to be able to purchase $5 \mathrm{~kg}$ food grains per eligible person per month at 3 (4.6屯 US) per $\mathrm{kg}$ for rice; wheat at 2 (3.1థ US) per kg and coarse grains (millet) at 1 (1.5\$ US) per kg.

The Group-II was economically in better position compared to Group-I, but they also fell under the low income category. Beneficiaries under Group-II were to be able to purchase $3 \mathrm{~kg}$ per eligible person per month of food grains at the price which was half of the procurement price.

Group-III consisted of section of people who were financially most affluent. The new bill had kept provisions of subsidised food grains for Group-I and Group-II only (GOI 2013).

Apart from these groups, pregnant women, lactating mothers, and certain categories of children were eligible for daily free meals under this law. The Bill implies that the government would have to spend minimum 1000 billion Rupees $^{2}$ (a conservative estimate) to procure food grains from the market and to supply it to the poorer section of the population at highly subsidised prices Sirkar (2013).

In a way, the National Food Security Act (NFSA) was the last attempt by the erstwhile UPA Government before the General Election of 2014 to give some respite to the economically most vulnerable group of the country. The UPA Government was quite confident that this bill would serve several purposes for the benefit of the poor people of the country. First, it would ensure food security for the poorest section of the population and second, it would constrain the increasing food inflation. Thirdly it would partially meet the objectives of Millennium Development Goal (MDG) which has to be fulfilled on or before 2015. This goal envisaged halving the proportion of poor people suffering from hunger during 1990 to 2015. In the context of Indian sub-continent, we find a perfect synergy between the basic objective of National Food Security Act (NFSA) and Millennium Development Goal (MDG).

In case of India, the erstwhile opposition vehemently protested against the bill apprehending further rise in food grain prices. The economic logics against the bill were more or less as follows:

Firstly, if the productivity of cultivation of food grain remains same, the fresh demand from government would only escalate the food grain prices through excess demand. Secondly, the poor people would demand more food items from the open market as they would now have more money left with them (because they will get food grains at cheaper prices from the public distribution system). Engel's law' states that as income increases the share of expenditure on food in total household expenditure tends to decrease. On the other hand, marginal propensity to consume on food items is more for the low income people. Similar incidence occurred after introduction of "100 Days Work" at the Panchayat level. Hence NFSA would indirectly induce more demand for food grains. Thirdly, the Public Distribution System (PDS) should be totally revamped 
to ensure food security. In the light of above arguments many new aspects of NFSA were highlighted and discussed threadbare. Some researchers work on typical PDS offered in different states. Among them Krishnamurty et al. 2014 deserved to mention. Krishnamurty et al. (2014) investigate whether food price subsidies affect household nutrition using a dramatic expansion of the availability of subsidized rice in the Indian State of Chhattisgarh in the early 2000's. They found that PDS reforms dramatically increased the availability of PDS food grains in the state relative to border districts. The households in Chhattisgarh increased their calorie consumption from pulses, animal-based protein, and produce (non-grains consumption) as the availability of subsidized rice expanded. This increase is driven by households eligible for rice subsidies, and there is no evidence that ineligible households changed their diet. These results contrast with recent studies suggesting that food subsidies have little effect on nutrition.

Mishra (2013) attempted to see the fiscal implications of the bill. Mishra (2013) said that the fiscal implications of the Food Security Act (FSA) were supposed to be significant. The cost of food subsidy because of implementation of FSA was estimated at Rs. 1245.02 billion for the fiscal year 2013-14. The cost was estimated to increase to Rs. Rs. 1577.010 billion in 2015-16. The additional food subsidy over and above the existing Targeted Public Distribution System (TPDS), which was the incremental cost to the budget, was estimated at Rs. 239.510 billion. This amounted to $0.2 \%$ of GDP.

Bhusan (2013) envisaged National Food Security Act (NFSA) as an effective tool in India's fight against malnutrition and food insecurity while Parikh (2013) focused on the impact of NFSA on hunger and malnutrition. Bhushan (2013) was apprehensive about the benefits of NFSA even though the same has been passed by both houses of the Parliament. Even the activists who had fought a long struggle to get this act passed were not satisfied. Skeptics see this act as mere populism and a waste of public money. For the skeptics, much of the debate that preceded the enactment of the NFSA revolved around the issue of cost of the NFSA and its impact on the economy. Shirur and Shivalinge (2014) examined implication of NFSA on Indian agriculture. The Act has potential to bring rich dividends especially in rural areas as access to food for poor means improvement in their productivity, labour efficiency, reduced expenditure on health and reduced migration to cities. However, the success of Act would depend on efficient grievance redressal, tackling corruption and stakeholders' active involvement. There are many others (Rammohan 2013, Kotwal et al. 2013, Swaminathan 2013) who raised either positive or negative side of NFSA.

There is still a shortage of adequate number of studies to measure all impacts of "Food Security Act". Most of the articles dealt with micro assessment of NFSA. None of the article focused on the economy wide impact including environment, land and price of National Food Security Act (NFSA) in a comprehensive manner. The attempt of our study was precisely in that direction.

In this background, the current paper evaluates the economy wide impact of implementing NFSA on the Indian economy using an Input-output (IO) framework. We have suitably aggregated the sectors of 2007-08 Input-output Table into 23 broad categories. The study also assesses the environmental impact of this act (NFSA) focusing on seven environmental indicators. These indicators include both air and water pollutions. Further the additional land requirement that NFSA entails has also been 
computed under the same framework. Most importantly, the study captures the sectoral price impact using a "Price Model" in Input-output framework. The impact of NFSA on labour and GDP growth of the nation has also been estimated.

The study attempts to measure the impacts of NFSA in terms of two scenarios. We have estimated two different projections of food grains demand by 2016-17. (1) The food grain demand for the nation at Business As Usual 2016-173 (Table 1 and Fig. 1) (Scenario 1). (2) The food grain demand including NFSA at 2016-17 named as NFSA Scenario (Scenario 2). As we know that NFSA generates food grain demand of minimum Rs. 1000 billion $^{4}$. We have assumed that the NFSA is implemented in Scenario 1 for the calculation of Scenario 2.

These two scenarios are suitably defined in the framework of our analysis. We have evaluated the implications of each of these situations in terms of demand for food grain and other sectors, sectoral growth, price impact, labour requirements, GDP growth, environmental impacts ${ }^{5}$ and land entailments.

Rest of the paper is organised as follows:

Section 2 calibrates the methods undertaken for the study. Section 3 gives a brief description of the sources of data used in this paper. This section also incorporates the aggregation scheme used in the paper. The results of our exercises have been discussed in Section 4. A brief conclusion is drawn based on our results in Section 5.

\section{Section 2: methods}

The most suitable methodology to capture knock-on effects of output change in an inter-dependant industrial scenario is Leontief model. Both direct and indirect linkage effects could be captured under this model to analyse sectoral impact of output change. However, Leontief model has been able to deal with only demand side implications of production function.

Later Ghosh (1958) introduced a method to capture supply side implications in Leontief framework. The model is able to find the "forward linkage" effect in an inter-dependent industry framework.

Table 1 Food grain production in India over time (in million tones)

\begin{tabular}{ll}
\hline Year & Food grain production (in million tonnes) \\
\hline $2001-02$ & 212.85 \\
$2002-03$ & 174.77 \\
$2003-04$ & 213.19 \\
$2004-05$ & 198.36 \\
$2005-06$ & 208.6 \\
$2006-07$ & 217.28 \\
$2007-08$ & 230.78 \\
$2008-09$ & 234.47 \\
$2009-10$ & 218.11 \\
$2010-11$ & 244.49 \\
$2011-12$ & 259.29 \\
$2012-13$ & 257.13 \\
\hline
\end{tabular}

Source: (Planning Commission 2013b) Agricultural Statistic Division, Directorate of Agriculture \& Cooperation, Government of India 


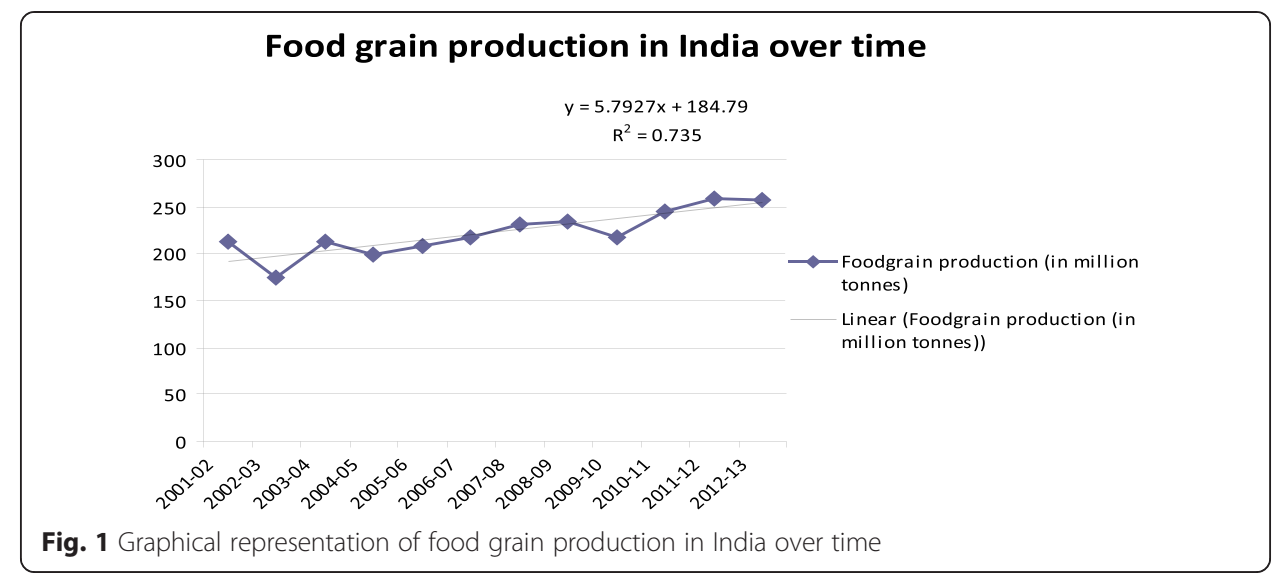

However, for our analysis, the basic form of system of equations of both the demanddriven and supply-driven models have to be modified to make the gross outputs of 'food grains' as exogenous in our system. The output figures in both Leontief and Ghosh model are treated as endogenous to the system whereas the demand figures are always considered exogenous. To consider food grains demand and supply fixed, we consider output of food grain as exogenous to the system. We develop a modified I-O framework for analysing resource mobilization issues to sustain long-term development goal in an economy. The system of equations has been modified accordingly to incorporate exogenous output figure of food grains. We are able to estimate the price impact due the implementation of NFSA using Ghosh model. Our study would primarily remain focused on measuring impact on rest of the economy so that the target (benchmark) production of food grain as per scenarios could be achieved. The detailed structure of the methodology is given below.

\section{Demand-driven input-output model (Leontief model)}

We would use the basic form of a demand-driven Leontief model with 23 commodities. Here the production function could be represented using matrix notations as:

$$
\mathbf{x}=(\mathbf{A x}+\mathbf{f})
$$

6

Where, $\mathbf{x}$ is total output vector $\left[\mathrm{x}_{\mathrm{i}}\right]_{23 \times 1}, \mathbf{A}$ is technical co-efficient matrix $\left[\mathrm{a}_{\mathrm{i}, j}\right]_{23 \times 23}$ and $\mathbf{f}$ is final demand vector $\left[\mathrm{f}_{\mathrm{i}}\right]_{23 \times 1}$

From equation (1), we can write:

$$
\mathbf{x}=(\mathbf{I}-\mathbf{A})^{-\mathbf{1}} \mathbf{f}
$$

From equation (2), for a change in $\mathrm{f}_{1}$ (which increases by Rs.100 billion after the implementation of National Food Security Bill), we calculate the corresponding production values in rest 22 sectors. The required growth rates are also calculated.

In the above calculation, $x_{i}$ is endogenous variable, whereas $f_{i}$ is treated as exogenous variable. This is the modification part of our analysis.

Now we apply NFSA targets for food grain sector. Here we take values of $x_{1}$ as fixed. The modified Leontief system of equation (Miller and Blair 2009) becomes: 


$$
\mathbf{A}^{\wedge} \mathbf{x}^{\wedge}=\mathbf{A} * \mathbf{f}^{\wedge}
$$

Where, $\mathbf{A}^{\wedge}$ is the (I-A) matrix with 1 st column as all zero and $\mathrm{a}_{1,1}$ is equal to -1 . $\mathbf{x}^{\wedge}$ is the output vector with 1 st row as endogenous $f_{1}$. Next $A^{*}$ is the unit matrix with 1 st column as $a_{j, 1}$ (for $j$ is equal to 1 to 23 ) and 1 st row is- $\left(1-a_{1,1}\right)$. Lastly, $\mathbf{f}^{\wedge}$ is the final demand vector whose elements are all exogenous $f_{i}$ (for $i$ is equal to 1 to 23 ) and 1st row is equal to exogenously fixed $\mathrm{x}_{1}$

Finally, equation (3) can be re-written as given in equation (4):

$$
\mathbf{x}^{\wedge}=\left(\mathbf{A}^{\wedge}\right)^{-\mathbf{1}} \mathbf{A} * \mathbf{f}^{\wedge}
$$

\section{Supply-driven input output model (Ghosh model)}

The basic form of a supply based Input-output model ${ }^{7}$ (with 23 industries) is represented below in equation 5 .

$$
\mathbf{x}=\mathbf{B}^{\mathbf{T}} \mathbf{x}+\mathbf{v}
$$

Where, $\mathbf{x}$ is total output vector $\left[\mathrm{x}_{\mathrm{i}}\right]_{23 \mathrm{x} 1}, \mathbf{B}$ is allocation co-efficient matrix $\left[\mathrm{b}_{\mathrm{i}, \mathrm{j}}\right]_{23 \times 23}$ and $\mathbf{v}$ is total value added vector $\left[\mathrm{v}_{\mathrm{j}}\right]_{23 \times 1}$

$\mathbf{B}^{\mathbf{T}}$ is the transpose matrix of $\mathbf{B}$

In this case, $x_{i}$ is endogenous variable, whereas $v_{j}$ is exogenous variable

Now we impose NFSA targets for food grain sector. Here also we take values of $\mathrm{x}_{1}$ fixed.

The modified Ghosh Model can be written in equation (6)

$$
\mathbf{B}^{\wedge} \mathbf{x}^{\wedge}=\mathbf{B} * \mathbf{v}^{\wedge}
$$

Where, $\mathbf{B}^{\wedge}$ is the $\left(\mathbf{I}-\mathbf{B}^{\mathbf{T}}\right)$ matrix with 1 st column as all zero and $b_{1,1}$ is equal to minus $1 . \mathbf{x}^{\wedge}$ is the output vector with 1 st row as endogenous $\mathbf{v}_{\mathbf{1}}$. Next $\mathbf{B}^{*}$ is the unit matrix with 1 st column as $b_{1, j}$ ( $j$ is equal to 1 to 23 ) and 1 st row is- $\left(1-b_{1,1}\right)$. Lastly, $\mathbf{v}^{\wedge}$ is the final value added vector whose elements are all exogenous $v_{j}$ ( $j$ is equal to 1 to 23 ) and 1 st row is equal to exogenously fixed $x_{j}$

And the solution of the system is given in equation (7):

$$
\mathbf{x}^{\wedge}=\left(\mathbf{B}^{\wedge}\right)^{-1} \mathbf{B} * \mathbf{v}^{\wedge}
$$

The above equation is solved for rest 22 sectors, considering output of food grain $\left(x_{1}\right)$ as exogenous. The output of food grain is fixed considering new demand from government sector into calculation.

\section{The price model}

When all inputs are taken into consideration in the processing and payments sectors, then the $\mathrm{j}$-th column sum (total outlays) is equal to the $\mathrm{j}$-th row sum (total output) (Miller and Blair 2009). Thus summing down the $\mathrm{j}$-th column, we get:

$$
\begin{aligned}
& x_{j}=\sum_{i=1}^{n} z_{i j}+v_{j} \\
& \mathbf{x}^{\mathbf{T}}=\mathbf{i}^{\mathbf{T}} \mathbf{Z}+\mathbf{v}^{\mathbf{T}}
\end{aligned}
$$

Where 


$$
\mathbf{v}^{\mathbf{T}}=\left(v_{1}, v_{2}, \ldots \ldots \ldots \ldots \ldots, v_{n}\right)
$$

Now, substituting

$$
\mathbf{Z}=\mathbf{A} \mathbf{x}^{\wedge}
$$

We get,

$$
\mathbf{x}^{\mathbf{T}}=\mathbf{i}^{\mathbf{T}} \mathbf{A} \mathbf{x}^{\wedge}+\mathbf{v}^{\mathbf{T}}
$$

Pre-multiplying by $\mathbf{x}^{\wedge}{ }^{-1}$ we get:

$$
\begin{aligned}
\mathbf{x}^{\mathrm{T}} \mathbf{x}^{\wedge}-\mathbf{1} & =\mathbf{i}^{\mathrm{T}} \mathbf{A} \mathbf{x}^{\wedge} \mathbf{x}^{\wedge}{ }^{-1}+\mathbf{v}^{\mathrm{T}} \mathbf{x}^{\wedge}{ }^{-1} \text { Or, }, \mathbf{i}^{\mathrm{T}}=\mathbf{i}^{\mathrm{T}} \mathbf{A}+\mathbf{v}^{\mathrm{T}}{ }_{\mathbf{c}} \text { Where, } \mathbf{v}^{\mathrm{T}}{ }_{\mathbf{c}} \\
& =\mathbf{v}^{\mathrm{T}} \mathbf{x}^{\wedge}{ }^{-1}=\left(\mathbf{v}_{\mathbf{1}} / \mathbf{x}_{\mathbf{1}}, \mathbf{v}_{\mathbf{2}} / \mathbf{x}_{\mathbf{2}}, \ldots \ldots . ., \mathbf{v}_{\mathbf{n}} / \mathbf{x}_{\mathbf{n}}\right)
\end{aligned}
$$

Here $\mathrm{Z}$ is the input co-efficient matrix, $\mathrm{X}^{\mathrm{T}}$ is the transpose of output vector $\mathrm{X}, \mathrm{V}^{\mathrm{T}}$ is transpose of value added matrix $\mathrm{V}, \mathrm{V}^{\mathrm{T}} \mathrm{C}$ is the product of $\mathrm{V}^{\mathrm{T}}$ and $\mathrm{X}^{\wedge-1}$.

The Right Hand Side of equation (9) represents cost of inputs per unit of output. Output prices are set equal to cost of production, so each price is equal to 1 (i.e. Left Hand Side).

If we denote the base year index prices by $\mathrm{p}^{\wedge}{ }_{\mathrm{j}}=\left(\mathrm{p}^{\wedge}{ }_{1}, \mathrm{p}^{\wedge}{ }_{2}\right.$ , $\mathrm{p}^{\wedge}$ ) the inputoutput price model is:

$$
\mathbf{p}^{\wedge} \mathbf{T}=\mathbf{p}^{\wedge}{ }^{\mathbf{T}} \mathbf{A}+\mathbf{v}^{\mathbf{T}}{ }_{\mathbf{c}} \mathrm{Or}, \mathbf{p}^{\wedge} \mathbf{T}=(\mathbf{I}-\mathbf{A})^{-1} \mathbf{v}^{\mathbf{T}}{ }_{\mathbf{c}}
$$

Transforming in terms of row vectors we have

$$
\mathbf{p}^{\wedge} \mathbf{T}=\left(\mathbf{I}-\mathbf{A}^{\mathbf{T}}\right)^{-\mathbf{1}} \mathbf{v}_{\mathbf{c}}
$$

\section{Impact on environment}

Total amount of pollution can be calculated as a function of output of industries. Then output of industries can be presented with interdependencies of industries and final demand. The pollution model is then prepared according to Leontief model as follows

Recollecting equation (2) we can structure the pollution equation as

$$
\mathrm{TP}_{\mathrm{i}=1 \ldots \mathrm{n}}=\mathrm{EZ}=\mathrm{E}(\mathrm{AX}+\mathrm{Y})=\mathrm{E}(\mathrm{I}-\mathrm{A})^{-1} \mathrm{Y}=\mathrm{ELY}
$$

Where $\mathrm{L}=(\mathrm{I}-\mathrm{A})^{-1}$

Here TP is a scalar giving the total quantity of pollution. And 'i' represents $\mathrm{CO} 2$, $\mathrm{CH} 4, \mathrm{~N} 2 \mathrm{O}, \mathrm{BOD}, \mathrm{COD}, \mathrm{SS}$ and DS generation from the industrial activity.

$\mathrm{E}$ is a vector of dimension (1xn) of coefficients for the industrial pollution intensity ${ }^{8}$ per unit of output. $\mathrm{X}$ is a vector $(\mathrm{nx} 1)$ of industrial output; $\mathrm{Y}$ is a $(\mathrm{n} \times 1)$ vector of final demand of industries; A is a ( $\mathrm{nxn}$ ) matrix of input-output coefficients describing interdependencies among input and output of industries; L is a Leontief matrix (nxn) giving industrial output per unit of final demand, inverse matrix of industrial output: $L=(I-A)^{-1}$. EL is a vector of (1xn) provides the total intensity of each type of pollutants.

\section{Labour requirement}

Using the concept of Leontief (1951) we have used factors of production-labour. 
Let $(\mathrm{I}-\mathrm{A})^{-1}$ be $(\mathrm{n} \times \mathrm{n})$ direct plus indirect intermediate input requirement matrix or Leontief Inverse, where $\mathrm{n}$ is the number of commodities. Also, let $\mathrm{F}$ be the matrix consisting of vector $\mathrm{L}$ which denote direct requirement of labour per unit of output.

Post multiplying the direct and indirect requirement matrix $(\mathrm{I}-\mathrm{A})^{-1}$, to the $\mathrm{F}$ matrix yields matrix B below,

$$
\mathrm{B}=\mathrm{F}(\mathrm{I}-\mathrm{A})^{-1}
$$

Where each row of the matrix $B$ gives direct plus indirect requirement of a factor (labour) per unit of each commodity's output.

\section{Section 3: data source}

Our primary source of data is the Input Output Transaction Table of 2007-08 published by Central Statistical Organization (CSO 2012), Government of India. This is a 130X130 commodity matrix used for Input Output Analysis.

To measure environmental implications of NFSA (i.e. GHG emission), we have considered the version 8 databases of GTAP (Global Trade Analysis Project) the reference year 2007. A standard GTAP framework provides estimates of the GHG emissions of different sectors. We have further computed the direct and total (direct and indirect) intensities of GHG emissions (CO2, CH4 and $\mathrm{N} 2 \mathrm{O}$ ).

The water pollution data (BOD, COD, SS and DS) has been taken from Chakraborty and Mukhopadhyay (2014) for the year 2007. This dataset has been used to prepare the direct and total intensities of individual water parameters.

Other important implications of NFSA include requirement of cultivable land to augment food grain production. The land data according to different agricultural sector has also been collected from GTAP databases (2001). We have also calculated the additional generation of labour requirement and GDP growth rate as a result of imposing National Food Security Act. We have calculated GDP coefficients from the Input Output Table of 2007-08. We have assumed that same GDP coefficients would prevail in 2016-17.

The sectoral employment/labour data for India have been compiled from Employment and Unemployment Surveys (EUS) of the National Sample Survey Organization (NSSO). The EUS 64th round, 2007-2008 (NSSO, 2012) have been used for compiling employment data for the year 2007-08. The labour coefficients have been calculated using the labour data from NSSO and total output data from the Input Output Table of 2007-08.

\section{Aggregation scheme}

We have suitably aggregated all the sectors of 2007-08 Input-output Transaction Table (at Factor Cost) for the purpose of our analysis. The 130X130 output matrix has been aggregated to 23X23 matrix. The detail description of each of these 23 sectors has been slated in Appendix. According to our aggregation scheme, sector 1 is the food grain sector.

\section{Section 4: results and discussions}

We present the results according to two scenarios as developed in Section 1. The food grains demand in 2007-8 was 230.78 million tonnes whose market value was INR. 
4033366.6 million at current prices. If the current trend continues, the projected food grain demand in 2016-17 would be 276 million tonnes according to the Business as Usual estimate (Scenario 1), value of projected food grains demand in 2016-2017 will be INR. 4823681.3 million (at 2007-2008 prices). Thus in Scenario 1 we have estimated the values of food grains for 2016-17 and capture its implications on other sectors.

On the other hand, Scenario 2 evaluates the impact of NFSA if implemented in Scenario 1. In this scenario we have added food grain demand of Rs. 1000 billion (as envisaged by NFSA) to Scenario 1 to arrive at Scenario 2. Taking production of food grains as exogenously fixed (and equal to INR. 4847625 million), we have calculated the demand for the remaining 22 sectors and also the price impact in the economy.

We have applied both Leontief and Ghosh model to estimate backward and forward linkage effects in an inter-dependent industry structure. .

The results pertaining to resulting outputs are presented in Table 2 . Similarly corresponding growth in outputs are presented in Table 3. The growth figures indicate sectors that are particularly important to achieve production targets. In other words, increase in food grain production (due to increased demand) must be supported by adequate growth in some related sectors in the economy. These sectors have been enlisted in Table 4. Sectors such as Chemicals \& chemical products, mineral fuels,

Table 2 Sectoral output of the Indian economy in India at 2016-17 in BAU and NFSA scenarios (Rs. Million)

\begin{tabular}{|c|c|c|c|c|c|}
\hline Sr. No. & Commodity & $\begin{array}{l}\text { Demand side } \\
\text { Scenario } 1\end{array}$ & $\begin{array}{l}\text { Demand side } \\
\text { Scenario } 2\end{array}$ & $\begin{array}{l}\text { Supply side } \\
\text { Scenario } 1\end{array}$ & $\begin{array}{l}\text { Supply side } \\
\text { Scenario } 2\end{array}$ \\
\hline 1 & Foodgrains & 4847625 & 5847625 & 4847625 & 5847625 \\
\hline 2 & Other oilseeds \& crops & 1569891 & 1585892 & 1583942 & 1619028 \\
\hline 3 & Plantation crops & 1138461 & 1141582 & 1137401 & 1139320 \\
\hline 4 & Fruits \& Vegetables & 1531171 & 1533829 & 1530569 & 1532592 \\
\hline 5 & Live Stock Products & 2843393 & 2899326 & 2828048 & 2867174 \\
\hline 6 & Forestry, Logging and Fishing & 1422978 & 1425381 & 1421241 & 1421527 \\
\hline 7 & Mineral Fuels & 1142333 & 1168841 & 1121018 & 1121367 \\
\hline 8 & Non-Fuel Minerals & 1286719 & 1292177 & 1282798 & 1283476 \\
\hline 9 & Food Products & 3748227 & 3756526 & 3794999 & 3864354 \\
\hline 10 & Textiles & 3554085 & 3561265 & 3551640 & 3556050 \\
\hline 11 & Wood Products & 1558329 & 1562694 & 1555782 & 1557086 \\
\hline 12 & Leather, Rubber and Plastic Products & 1736103 & 1740581 & 1735047 & 1738403 \\
\hline 13 & Petroleum \& Coal Tar Products & 4399407 & 4427739 & 4377627 & 4379298 \\
\hline 14 & Chemicals \& Chemical Products & 3714162 & 3806953 & 3644663 & 3652508 \\
\hline 15 & Non-Metallic Mineral Products & 1448816 & 1453126 & 1446274 & 1447528 \\
\hline 16 & Iron \& Steel Products & 3624835 & 3634216 & 3619173 & 3621739 \\
\hline 17 & Non-Electrical Equipments & 4098836 & 4110875 & 4091409 & 4094487 \\
\hline 18 & Electrical \& Electronics Equipments & 2102333 & 2106325 & 2100370 & 2102040 \\
\hline 19 & Transport \& Transport Equipments & 9757032 & 9797452 & 9731863 & 9741897 \\
\hline 20 & Precision Tools & 255903.2 & 256172.1 & 255845.6 & 256056.5 \\
\hline 21 & Miscellaneous Manufacturing Products & 1790360 & 1792111 & 1790183 & 1791803 \\
\hline 22 & Amenity Infrastructure & 14000000 & 14100000 & 14000000 & 14000000 \\
\hline 23 & All Services & 26700000 & 26800000 & 26700000 & 26700000 \\
\hline
\end{tabular}


Table 3 Required growth rates (\%) in BAU and NFSA scenario at 2016-17

\begin{tabular}{|c|c|c|c|c|c|}
\hline & & Demand side & Demand side & Supply side & Supply side \\
\hline Sr. No & Commodity & Scenario 1 & Scenario 2 & Scenario 1 & Scenario 2 \\
\hline 1 & Foodgrains & 20.19 & 44.98 & 20.19 & 44.98 \\
\hline 2 & Other oilseeds \& crops & 0.84 & 1.86 & 1.74 & 3.99 \\
\hline 3 & Plantation crops & 0.22 & 0.50 & 0.13 & 0.30 \\
\hline 4 & Fruits \& Vegetables & 0.14 & 0.32 & 0.10 & 0.23 \\
\hline 5 & Live Stock Products & 1.63 & 3.63 & 1.08 & 2.48 \\
\hline 6 & Forestry, Logging and Fishing & 0.14 & 0.31 & 0.02 & 0.04 \\
\hline 7 & Mineral Fuels & 1.93 & 4.29 & 0.02 & 0.06 \\
\hline 8 & Non-Fuel Minerals & 0.35 & 0.77 & 0.04 & 0.09 \\
\hline 9 & Food Products & 0.18 & 0.40 & 1.43 & 3.28 \\
\hline 10 & Textiles & 0.16 & 0.37 & 0.10 & 0.22 \\
\hline 11 & Wood Products & 0.23 & 0.51 & 0.06 & 0.15 \\
\hline 12 & Leather, Rubber and Plastic Products & 0.21 & 0.47 & 0.15 & 0.34 \\
\hline 13 & Petroleum \& Coal Tar Products & 0.53 & 1.17 & 0.03 & 0.07 \\
\hline 14 & Chemicals \& Chemical Products & 2.08 & 4.63 & 0.17 & 0.38 \\
\hline 15 & Non-Metallic Mineral Products & 0.24 & 0.54 & 0.07 & 0.15 \\
\hline 16 & Iron \& Steel Products & 0.21 & 0.47 & 0.05 & 0.13 \\
\hline 17 & Non-Electrical Equipments & 0.24 & 0.53 & 0.06 & 0.13 \\
\hline 18 & Electrical \& Electronics Equipments & 0.15 & 0.35 & 0.06 & 0.14 \\
\hline 19 & Transport \& Transport Equipments & 0.34 & 0.75 & 0.08 & 0.18 \\
\hline 20 & Precision Tools & 0.09 & 0.19 & 0.06 & 0.15 \\
\hline 21 & Miscellaneous Manufacturing Products & 0.08 & 0.18 & 0.07 & 0.16 \\
\hline 22 & Amenity Infrastructure & 0.27 & 0.60 & 0.05 & 0.11 \\
\hline 23 & All Services & 0.33 & 0.74 & 0.22 & 0.40 \\
\hline
\end{tabular}

livestock products and other oilseed \& crops are most important from demand perspective for these scenarios. The key sectors identified from supply side are other oilseeds \& crops, food products and livestock products. Hence we can clearly sort out that other oilseeds \& crops and live stock products are the most important from all perspective. These two sectors growth is essential to increase in food grain productions.

Table 4 Key sectors' in BAU and NFSA scenarios

\begin{tabular}{lll}
\hline & Demand side & Supply side \\
\hline Scenario 1 & 1) Chemicals \& chemical products & 1) Other Oilseeds \& crops \\
& 2) Mineral fuels & 2) Food products \\
3) Live Stock Products & 3) Live Stock Products \\
4) Other oilseed \& crops & \\
Scenario 2 & 1) Chemicals \& Chemical Products & 1) Other oilseeds \& crops \\
2) Mineral Fuels & 2) Food Products \\
3) Live Stock Products & 3) Live Stock Products \\
4) Other oilseeds \& crops & 4) All Services \\
5) Petroleum \& Coal Tar Products & 5) Chemicals \& Chemical Products
\end{tabular}


Since other oilseeds \& crop is the primary source of edible oils, it is required in almost all processed food items and wide range of culinary. For this reason with the growth in food grains, the supply of other oilseeds and crops needs to grow substantially. As other oil seeds and crops are becoming costlier, the tendency towards crop diversification intensifies. Farmers tend to replace pulses and cereal production with more of oil seed production. The minimum support price of food grains should be sufficiently high to restrain this. Otherwise, food grain production would decrease and the food security of the country would be jeopardised.

Importance of live stock products indicates that the rise in food grain consumption must be accompanied by consumption of live stock products like meat, egg etc. Then only a balanced diet for the consumers could be ensured. Food grain is the largest source of carbohydrates. Hence any increase in food grains must be complemented with adequate protein intake. Live stock products ensure that protein intake.

The result of GDP and labour impact due to NFSA is presented in Table 5. The additional labour requirement due to NFSA $2016-17$ is likely to be 48114.3 million (6.21 \%) compared to BAU 2016-17. The direct major labour generation is expected from food grains sector (44203.77 million). The indirect additional labour requirement (3910.591 million) can also be estimated from this exercise. Apart from food grains sector, the other key sectors contribution in labour generation are oilseed, livestock, mineral fuels, chemical and chemical products, petroleum products, transport equipment and other services (Table 6).

\section{Impact on prices}

According to the BAU scenario, India would demand 277.37 million tonnes of food grains in 2016-2017. We presume that introduction of NFSA would not have any effect on the intrinsic agricultural productivity of the country. Rather, it would only artificially scale up the price level. For simplicity we assume that increase in value of food grains occurs solely due to food inflation.

The food grains demand was 230.78 million tonnes in 2007-08 and its market value was Rs. 4033366.6 million. The value of projected food grain demand in 2016-17 (i.e 277.37 million tonnes) would be Rs. 4847625 million (2007-08 prices), as a result the increase in food grain demand value in 2016-17 would be of Rs. 814258.4 million.

We applied the Leontief price model, to find the increase in price level due to additional demand in food grain prices. The results give us inflation level of each commodity under NFSA (scenario 2).

Impact on prices due to imposition of NFSA shows that the food grain inflation is expected to be high. The percentage increase in price change is presented in Table 7. Increases

Table 5 Labour generation and GDP growth in BAU and NFSA scenario

\begin{tabular}{lr}
\hline DD side & $2016-17$ \\
\hline Total Labour generation in scenario 1(BAU)in million & 764913.8 \\
Total Labour generation in scenario 2(FSA) in million & 813028.1 \\
Additional Labour generation due to FSA 2016-17 from BAU 2016-17 in million & 48114.36 \\
Additional labour growth in FSA scenario compared to BAU2016-17 (\%) & 6.21 \\
Total additional GDP growth expected due to FSA scenario (\%) & 1.51 \\
\hline
\end{tabular}


Table 6 Additional generation of Sectoral labour growth in NFSA compared to BAU 2016-17 (\%)

\begin{tabular}{llc}
\hline & Sectors & \% change \\
\hline 1 & Food grains & 20.62866 \\
2 & Other oilseeds \& crops & 1.019286 \\
3 & Live Stock Products & 1.967102 \\
4 & Mineral Fuels & 2.320531 \\
5 & Petroleum \& Coal Tar Products & 0.643993 \\
6 & Chemicals \& Chemical Products & 2.498304 \\
7 & Transport \& Transport Equipments & 0.414266 \\
8 & All Services & 0.408133 \\
\hline
\end{tabular}

in food grain prices normally have widespread inflationary impact. Since food grain is consumed by all, any price hike is percolated to other sectors easily. High inflation is observed in commodities like Miscellaneous Manufacturing Products, Electrical \& Electronics Equipments, Non-Electrical Equipments, Precision Tools, Chemical and Chemical Products, Leather, Rubber and Plastic Products, Non-Metallic Mineral Products, Amenity Infrastructure, Iron and Steel Products and Transport \& Transport Equipments. Hence inflationary impact of increase in food grain demand is more on industrial and infrastructural commodities.

In India, many people are involved in out-of-the-farm activities and produce small machineries, equipments and chemicals, etc. According to the Government of India, Micro,

Table 7 Price impact (\%) due to imposition of National Food Security Act (NFSA)

\begin{tabular}{|c|c|c|}
\hline Sr. No & Commodity & (\%) in price \\
\hline 1 & Miscellaneous Manufacturing Products & 1.221563238 \\
\hline 2 & Electrical \& Electronics Equipments & 1.204246636 \\
\hline 3 & Non-Electrical Equipments & 1.198840196 \\
\hline 4 & Precision Tools & 1.180753883 \\
\hline 5 & Chemicals \& Chemical Products & 1.169174915 \\
\hline 6 & Leather, Rubber and Plastic Products & 1.164877981 \\
\hline 7 & Non-Metallic Mineral Products & 1.142949778 \\
\hline 8 & Amenity Infrastructure & 1.126452148 \\
\hline 9 & Iron \& Steel Products & 1.118724802 \\
\hline 10 & Transport \& Transport Equipments & 1.114337531 \\
\hline 11 & Textiles & 1.09512835 \\
\hline 12 & Non-Fuel Minerals & 1.074932361 \\
\hline 13 & Wood Products & 1.054975417 \\
\hline 14 & Foodgrains & 0.952593686 \\
\hline 15 & Petroleum \& Coal Tar Products & 0.919521103 \\
\hline 16 & Food Products & 0.890878703 \\
\hline 17 & Other oilseeds \& crops & 0.773827518 \\
\hline 18 & Live Stock Products & 0.769350685 \\
\hline 19 & Mineral Fuels & 0.707871878 \\
\hline 20 & Plantation crops & 0.639805435 \\
\hline 21 & All Services & 0.563439167 \\
\hline 22 & Forestry, Logging and Fishing & 0.408437176 \\
\hline 23 & Fruits \& Vegetables & 0.23281226 \\
\hline
\end{tabular}


Small and Medium Enterprises (MSME) contribute nearly eight per cent of the country's GDP, $45 \%$ of the manufacturing output and $40 \%$ of the exports. They provide the largest share of employment after agriculture. They are the nurseries for entrepreneurship and innovation. They are widely dispersed across the country and produce a diverse range of products and services to meet the needs of the local markets, global market, and national and international value chains. ${ }^{9}$ As food grain prices increase, the employees ask for dearness allowances and thus the unit cost of production rises. As a result, the price of machineries and equipments produced mostly by MSME sector also rises (Chhibber 2013).

The current exercise presents the likely impact of recent NFSA on the Indian economy. Previous literatures have already assessed targeted PDS initiated by the government at State level as well as national level. Most of them have outlined a negative feedback. Many studies suggest that the Minimum Support Price (MSP) of the government provides mostly income support to farmers rather than to stabilize food prices (Rakshit 2003). Kaushal and Muchomba (2013) found evidence that the decline in the price of wheat and rice, changed consumption patterns toward increased consumption of wheat and rice and lower consumption of coarse grains, the unsubsidized staple food. It suggests that food price subsidies are likely to affect agriculture markets without impacting nutrition.

The NFSA aims to expand and improve the distribution of food grains through the PDS. Despite this large, projected increase in expenditure on food aid, previous research provides no evidence that expanding the PDS in its current form will improve calorie consumption or diet quality in India (Kaushal and Muchomba 2013, Tarozzi 2005). The NFSA has also been criticized for focusing on grains instead of pulses and other foods that would help diversify a diet that is overly reliant on grains. However, Krishnamurthy et al. 2014 suggest that the proposed expansion of the PDS under the NFSA could help to reduce persistent malnourishment and food insecurity in the country because of an improvement in non grains consumption.

Bhushan (2013) and Shirur and Gowda (2014) even though depict the benefits of NFSA, however, concerned about the burden of cost, corruption and stakeholders involvement.

The effects of government procurement on agricultural markets are likely to be magnified, given the potential increase in the procurement under the NFSA. A number of policy makers are therefore concerned about the NFSB's implications for agricultural markets. The chairman of India's Commission for Agricultural Costs and Prices says that "more spending on welfare programs-especially when that spending relies on a flawed system-is reckless in an economy burdened by a weakened currency and a large fiscal deficit". "The economic inefficiencies and the losses incurred in the system will outweigh the welfare gains" (Gulati et al. 2012).

\section{Impact on the environment}

The increase in food grain production ${ }^{10}$ has wide spread repercussions. In this paper we have identified environment and land usage impact of imposing NFSA.

Any increase in production activities usually leaves strong impact on environment in terms of generation of pollutants (both air and water). Any productive activity must conform to the environmental norms of the country. Otherwise the activity, though productive, may not be considered as sustainable. For successful implementation of any 
expansionary policy, the economic impacts must be productive as well as sustainable. Success of NFSA hinges on that too.

Following standard procedures explained in modeling section, we have calculated the BAU and NFSA scenarios ${ }^{11}$ impact on the environment at 2016-17. The impact on air pollution is cited in Table 8 . We found that the amount of air pollution in million metric tonne $\mathrm{CO} 2$ equivalent has been maximum for $\mathrm{N} 2 \mathrm{O}$ followed by $\mathrm{CH} 4$. Results of two scenarios indicate that $\mathrm{N} 2 \mathrm{O}$ is the most prevalent form of air pollutant. As a result of imposition of NFSA, the $\mathrm{N} 2 \mathrm{O}$ emission is likely to increase on average by $7.85 \%$. This is substantial in any standard. The other indicators of GHG emissions such as $\mathrm{CO} 2$ and $\mathrm{CH} 4$ are also likely to add around $1 \%$ due to NFSA relative to BAU.

The level of water pollution due to imposition of NFSA have been presented in Table 9. Water pollution in thousand tonnes reveals that maximum amount of pollutant generated is BOD followed by COD. An additional $13.6 \%$ of BOD and $11.5 \%$ of COD are expected to generate due to NFSA scenario.

Similar calculation for the changes in requirement of cultivable land due to imposition of Food Security Act is presented in Table 10. Our computation shows that the additional land requirement due to imposition of NFSA is substantial (35005.4 ha).

Overall, we found that the impact on environment of National Food Security Act is not favourable. Our result shows that the economy is likely to generate additional GHG emissions of 10.38 million metric tonne of $\mathrm{CO} 2$ equivalent (including $\mathrm{CO} 2, \mathrm{CH} 4$ and $\mathrm{N} 2 \mathrm{O}$ ) due to this act. A significant generation of water pollution (including BOD, COD, Suspended Solids and Dissolved Solids) is also expected. The overall land requirement on account of NFSA has been found to be significant. Hence, availability of land could also be a serious impediment to the implementation of Food Security bill.

\section{Section 5: conclusion}

Development of a systematic framework to manage global food security has become a priority for the global community. India faces the challenge and pressure to feed over 1.25 billion people. Despite economic growth and self-sufficiency in food grains production, high levels of poverty, food insecurity and malnutrition persist in India (WFP 2015). The National Food Security Act (NFSA) passed in 2013 is a milestone in the history of India's fight against hunger and malnutrition, as it claims to feed more than 800 million Indians ${ }^{12}$ with highly subsidised staple foods (WFP 2015). In this backdrop, the current paper evaluates the economy wide impact of NFSA on the Indian economy. It estimates the labour requirement, GDP growth, and indirect impact on the other sector of the economy. The paper also measures the impact as a result of NFSA on prices of different sectors of the economy. The Impact on environment including air and water pollution as well as land requirement has also been calculated.

Table 8 Amount of air pollution in various scenarios (in million metric tonne of CO2 equivalent)

\begin{tabular}{lrrrrc}
\hline GHG emission & $2007-08$ & $2016-17$ & \% Increase & NFSA 2016-17 & $\begin{array}{l}\text { \% Increase at NFSA compared } \\
\text { to BAU 2016-17 }\end{array}$ \\
\hline CO2 & 1191.03 & 1212.51 & 1.80 & 1221.24 & 0.72 \\
N2O & 12.63 & 15.65 & 23.92 & 16.88 & 7.85 \\
CH4 & 44.46 & 45.51 & 2.35 & 45.93 & 0.93 \\
\hline
\end{tabular}


Table 9 Amount of water pollution in various scenarios (in thousand tonnes)

\begin{tabular}{llllll}
\hline Water pollution & \multicolumn{5}{c}{} \\
\hline & $2007-08$ & BAU 2016-17 & \% Increase & NFSA 2016-17 & $\begin{array}{l}\text { \% Increase at NFSA } \\
\text { compared to BAU 2016-17 }\end{array}$ \\
SS & 208927.55 & 229041.48 & 9.63 & 237223.72 & 3.57 \\
DS & 66202.78 & 66994.87 & 1.20 & 67317.09 & 0.48 \\
BOD & 96891.31 & 145862.78 & 50.54 & 165784.12 & 13.66 \\
COD & 198649.74 & 277382.63 & 39.63 & 309410.76 & 11.55 \\
\hline
\end{tabular}

Results from all the scenarios show that the other sectors which need to gear up significantly to supplement targeted growth in food grain sector are Chemicals and chemical products, Mineral fuels, Livestock products and other oil seeds and crops. The additional labour and GDP growth due to NFSA is expected at $6.21 \%$ and $1.51 \%$ respectively compared to 2016-17.

From this exercise, we observe that to implement NFSA, the production structure of agricultural sector has to be revised thoroughly. What is needed would be increase in productivity rather than increase in acreage area. Given the same area of cultivable land, productivity has to improve substantially. For this to happen, use of fertilizers, pesticides, intense irrigation and modern agricultural equipments would be required. The entire system has to upgrade significantly.

However, there is a bigger threat of increasing productivity using fertilizers and pesticides. The problem of ecological hazard may creep in which could foil the entire production process. Because of this reason, the concepts of integrated nutrient management and integrated pest management have gained popularity. In this regard, we have calculated the environmental impact of National Food Security Bill using Input-output framework. Our results show that the environmental impact (air and water pollution) of food security bill is not favourable. The direct and indirect pollution intensities are sizeable which can cause serious damage to our ecosystem. The economy is likely to generate additional GHG emissions of 10.39 million metric tonne of $\mathrm{CO} 2$ equivalent due to this act. A significant generation of $\mathrm{BOD}$ and $\mathrm{COD}$ is also expected. The total land requirement as a result of food security bill has also been calculated to be huge.

Availability of land could be a serious impediment to the implementation of Food Security bill.

To make the NFSA more sustainable, changes in farming practices can offer big opportunities toward reduction in GHG emission. On the supply side, crop management practices-such as improved fertilizer management and conservation tillage-offer the greatest reduction potential at relatively low costs. Better managing grazing lands-such as by rotational grazing and altering forage composition-and restoring degraded lands and cultivated organic soils into productivity are also important (WRI 2014).

The analysis still leaves a number of questions unanswered.

Another important constraint of food security in India is the availability of fresh water for cultivation. The increase in production of food grains would also entail significant

Table 10 Additional land requirement (in Hectares) in NFSA Scenarios compared to BAU 2016-17

\begin{tabular}{lccc}
\hline & NFSA 2016-17 & BAU 2016-17 & \% increase \\
\hline Land requirement (in hectares) & 348184.93 & 313179.53 & 11.18 \\
\hline
\end{tabular}


requirement of fresh water, which is currently under pressure. Gross water demand for all users in India is estimated to grow up from 750 BCM in 2000 to 1027 BCM by 2025 . The gross water demand by irrigation sector alone is estimated to be 730 BCM by 2015 (Brahmanand et al, 2013). Hence increase in production of food grains would entail significant requirement of fresh water, which may not be available in future.

In India, other threats to food security include crop diversification, replacement of food grain production by bio-fuel and medicinal plants, adverse climate change, acquisition of cultivable land for establishing industrial Special Economic Zones (SEZ) etc.

Since in India, most of the farm sizes are small and fragmented, the productivity might have reached a saturation point where no significant improvement in productivity is possible. In this case, the only option left is to supplement "National Food Security Act" by import food grains. But that would result in huge burden on country's exchequer. Food Security Act nowhere hinted about that. There could also be a reallocation of farm land from non food grain to food grain sector. But that may have negative repercussion on availability of non-food grains and cash crops like tea, jute, rubber etc. This would again have a negative impact on country's exchequer, as most of the non-food items are exported. Replacing cultivation of cash crops by food grains is not always feasible. ${ }^{13}$ It depends a lot on the texture of soil, its fertility and local climate. There would be always a tendency of increase in food grain prices. This inherent tendency could surmount any attempt to control it by Government or any other agency. The inflationary pressure would not be confined within the periphery of agricultural sector rather it would spill over to other sectors which seemingly do not have any relation to food grain production, for example "Precision Tools".

There are also some fears being propagated that this bill can actually harm the economy. One is in relation to the amount of food grains required and its impact on farmers, production and procurement. The second fear is that it will all be "money down the drain" because of the high leakages/diversion and wastage in the PDS. The extent of leakages in the PDS certainly is a cause for concern (Sinha 2013). According to Montek Singh Ahluwalia, former Deputy-Chairman of the Planning Commission of India, only $16 \%$ of the resources allocated towards India's food subsidized distribution scheme reach the poor (Economist 2010). Hence without re-vamping of PDS system, introduction of NFSA could be a complete disaster.

The current study also throws some insight on the achievements of The Millennium Development Goals (MDG) which conclude in 2015 in the context of NFSA. It has been found that in India, absolute poverty has declined to some extent but income inequality became alarming making other targets of MDG less accessible. While per capita income in India has more than tripled in the last two decades, the minimum dietary intake reduced during the same period. The bottom $10 \%$ of the population account for only $3.6 \%$ of the total consumption expenditure and the top $10 \%$ accounts for $31 \%$; the gap between the rich and the poor has increased during the high economic growth phase (WFP 2015). The success of NFSA would also be highly constrained if socio-economic factors like income inequality do not improve substantially over time.

From this exercise we could manage to contribute to the food security literature by focusing on economic and environmental impact due to the implementation of NFSA. There are several other impacts which need to be highlighted in the context of food security act. A mixed outcome is expected from the Food Security Bill. The bill lacks proper 
and effective enforcement machinery. The feasibility of the bill has to be tested on the ground. However, the bill should have the capability to yield good results in near future.

\section{Endnotes}

${ }^{1}$ Public Distribution System (PDS) is said to have existed from before independence in India, and was initially intended to protect consumers from food shortages and producers from price fluctuations (Tarozzi 2002). It was originally started at a few urban centres, but was extended in the 1980s as a measure for food security and poverty alleviation (Kattumuri 2011). Central and state governments jointly manage PDS with the centre being responsible for procurement, storage, transportation and allocation. The states are responsible for the distribution through fair price shops; as well as for identification of families below poverty line (BPL), issuing cards, supervision and monitoring.

2"Ektu Beshi Bhat Chaileo Paben Na”; Abhirup Sirkar,; Ananda Bazar Patrika.There are various estimates regarding the NFSB. The current study considers a most conservative estimate. According to the Ministry of Agriculture, the food subsidy alone will cost the Exchequer about Rs 950 billion to start with. The Bill may touch an expenditure of anywhere between Rs 1250 to 1500 billion, if the Bill adds up the associated set up expenditure of the existing Public Distribution System. To ensure ample grain supplies on sustainable basis under the NFSB, an expenditure of Rs 1106 billion would be needed over a five year period (Gulati et al. 2012).

${ }^{3}$ End of the Twelfth plan period, GOI-2012-17

${ }^{4} 1000$ billion rupees $=$ USD 63090 billion $(1 \mathrm{USD}=63.09 \mathrm{INR})$

${ }^{5}$ The global food system, from fertilizer manufacture to food storage and packaging, is responsible for up to one-third of all greenhouse-gas emissions, according to the Consultative Group on International Agricultural Research (CGIAR). Emissions generated during the application of synthetic fertilizers accounted for $13 \%$ of agricultural emissions in 2011, and are the fastest growing emissions source in agriculture, having increased some $37 \%$ since 2001. Greenhouse gases resulting from biological processes in rice paddies that generate methane make up $10 \%$ of total agricultural emissions, while the burning of savannahs accounts for $5 \%$ (FAO 2014).

${ }^{6} \mathrm{We}$ consider that the outputs in 23 sectors are $\mathrm{x}_{1}, x_{2}, \ldots \ldots ., \mathrm{x}_{23}$ where $\mathrm{x}_{1}$ is the output in food grains sector. The corresponding final demands are $f_{1}, f_{2}, \ldots \ldots . ., f_{23}$.

${ }^{7}$ This model assumes Constant Allocation Coefficients.

${ }^{8}$ In this exercise we have 7 types of pollutants (CO2, CH4, N2O, BOD, COD, SS and DS).

${ }^{9}$ Ministry of Micro, Small and Medium Enterprises, Government of India.

${ }^{10}$ to commensurate equivalent food grain demand

${ }^{11}$ The increase in pollution at BAU 2016-17 is measured in scenario 1 . Scenario 2 is based on NFSA impact at 2016-17 (i.e food grain demand of additional one thousand billion is taken into consideration)

${ }^{12} 75 \%$ of the rural and $50 \%$ of the urban population living below and just above the national poverty line (GOI 2013)

${ }^{13}$ For example we cannot grow wheat on tea gardens. 


\section{Appendix}

Table 11 Aggregation scheme

\begin{tabular}{|c|c|c|c|}
\hline $\begin{array}{l}\text { Sector/ Code } \\
\text { as per IOTT }\end{array}$ & Commodity & Aggregation Scheme & $\begin{array}{l}\text { Code as per our } \\
\text { study }\end{array}$ \\
\hline 1 & Paddy & Foodgrains & 1 \\
\hline 2 & Wheat & Foodgrains & 1 \\
\hline 3 & Jowar & Foodgrains & 1 \\
\hline 4 & Bajra & Foodgrains & 1 \\
\hline 5 & Maize & Foodgrains & 1 \\
\hline 6 & Gram & Foodgrains & 1 \\
\hline 7 & Pulses & Foodgrains & 1 \\
\hline 11 & Other oilseeds & Other oilseeds \& crops & 2 \\
\hline 20 & Other crops & Other oilseeds \& crops & 2 \\
\hline 8 & Sugarcane & Plantation crops & 3 \\
\hline 9 & Groundnut & Plantation crops & 3 \\
\hline 10 & Coconut & Plantation crops & 3 \\
\hline 12 & Jute & Plantation crops & 3 \\
\hline 13 & Cotton & Plantation crops & 3 \\
\hline 14 & Tea & Plantation crops & 3 \\
\hline 15 & Coffee & Plantation crops & 3 \\
\hline 16 & Rubber & Plantation crops & 3 \\
\hline 17 & Tobacco & Plantation crops & 3 \\
\hline 18 & Fruits & Fruits \& Vegetables & 4 \\
\hline 19 & Vegetables & Fruits \& Vegetables & 4 \\
\hline 21 & Milk and milk products & Live Stock Products & 5 \\
\hline 22 & Animal services(agricultural) & Live Stock Products & 5 \\
\hline 23 & Poultry \& Eggs & Live Stock Products & 5 \\
\hline 24 & Other liv.st. produ. & Live Stock Products & 5 \\
\hline 25 & Forestry and logging & Forestry, Logging and Fishing & 6 \\
\hline 26 & Fishing & Forestry, Logging and Fishing & 6 \\
\hline 27 & Coal and lignite & Mineral Fuels & 7 \\
\hline 28 & Natural gas & Mineral Fuels & 7 \\
\hline 29 & Crude petroleum & Mineral Fuels & 7 \\
\hline 30 & Iron ore & Non-Fuel Minerals & 8 \\
\hline 31 & Manganese ore & Non-Fuel Minerals & 8 \\
\hline 32 & Bauxite & Non-Fuel Minerals & 8 \\
\hline 33 & Copper ore & Non-Fuel Minerals & 8 \\
\hline 34 & Other metallic minerals & Non-Fuel Minerals & 8 \\
\hline 35 & Lime stone & Non-Fuel Minerals & 8 \\
\hline 36 & Mica & Non-Fuel Minerals & 8 \\
\hline 37 & Other non metallic minerals & Non-Fuel Minerals & 8 \\
\hline 80 & Non-ferrous basic metals & Non-Fuel Minerals & 8 \\
\hline 38 & Sugar & Food Products & 9 \\
\hline 39 & Khandsari, boora & Food Products & 9 \\
\hline
\end{tabular}


Table 11 Aggregation scheme (Continued)

\begin{tabular}{|c|c|c|c|}
\hline 40 & Hydrogenated oil(vanaspati) & Food Products & 9 \\
\hline 41 & Edible oils other than vanaspati & Food Products & 9 \\
\hline 42 & Tea and coffee processing & Food Products & 9 \\
\hline 43 & Miscellaneous food products & Food Products & 9 \\
\hline 44 & Beverages & Food Products & 9 \\
\hline 45 & Tobacco products & Food Products & 9 \\
\hline 46 & Khadi, cotton textiles(handlooms) & Textiles & 10 \\
\hline 47 & Cotton textiles & Textiles & 10 \\
\hline 48 & Woolen textiles & Textiles & 10 \\
\hline 49 & Silk textiles & Textiles & 10 \\
\hline 50 & Art silk, synthetic fiber textiles & Textiles & 10 \\
\hline 51 & Jute, hemp, mesta textiles & Textiles & 10 \\
\hline 52 & Carpet weaving & Textiles & 10 \\
\hline 53 & Readymade garments & Textiles & 10 \\
\hline 54 & Miscellaneous textile products & Textiles & 10 \\
\hline 55 & Furniture and fixtures-wooden & Wood Products & 11 \\
\hline 56 & Wood and wood products & Wood Products & 11 \\
\hline 57 & Paper, paper prods. \& newsprint & Wood Products & 11 \\
\hline 58 & Printing and publishing & Wood Products & 11 \\
\hline 59 & Leather footwear & Leather, Rubber and Plastic Products & 12 \\
\hline 60 & Leather and leather products & Leather, Rubber and Plastic Products & 12 \\
\hline 61 & Rubber products & Leather, Rubber and Plastic Products & 12 \\
\hline 62 & Plastic products & Leather, Rubber and Plastic Products & 12 \\
\hline 63 & Petroleum products & Petroleum \& Coal Tar Products & 13 \\
\hline 64 & Coal tar products & Petroleum \& Coal Tar Products & 13 \\
\hline 65 & Inorganic heavy chemicals & Chemicals \& Chemical Products & 14 \\
\hline 66 & Organic heavy chemicals & Chemicals \& Chemical Products & 14 \\
\hline 67 & Fertilizers & Chemicals \& Chemical Products & 14 \\
\hline 68 & Pesticides & Chemicals \& Chemical Products & 14 \\
\hline 69 & Paints, varnishes and lacquers & Chemicals \& Chemical Products & 14 \\
\hline 70 & Drugs and medicines & Chemicals \& Chemical Products & 14 \\
\hline 71 & Soaps, cosmetics \& glycerin & Chemicals \& Chemical Products & 14 \\
\hline 72 & Synthetic fibers, resin & Chemicals \& Chemical Products & 14 \\
\hline 73 & Other chemicals & Chemicals \& Chemical Products & 14 \\
\hline 74 & Structural clay products & Non-Metallic Mineral Products & 15 \\
\hline 75 & Cement & Non-Metallic Mineral Products & 15 \\
\hline 76 & Other non-metallic mineral prods. & Non-Metallic Mineral Products & 15 \\
\hline 77 & Iron, steel and ferro alloys & Iron \& Steel Products & 16 \\
\hline 78 & Iron and steel casting \& forging & Iron \& Steel Products & 16 \\
\hline 79 & Iron and steel foundries & Iron \& Steel Products & 16 \\
\hline 81 & Hand tools, hardware & Non-Electrical Equipments & 17 \\
\hline 82 & Miscellaneous metal products & Non-Electrical Equipments & 17 \\
\hline 83 & Tractors and agri. Implements & Non-Electrical Equipments & 17 \\
\hline
\end{tabular}


Table 11 Aggregation scheme (Continued)

\begin{tabular}{|c|c|c|c|}
\hline 84 & Industrial machinery $(F \& T)$ & Non-Electrical Equipments & 17 \\
\hline 85 & Industrial machinery(others) & Non-Electrical Equipments & 17 \\
\hline 86 & Machine tools & Non-Electrical Equipments & 17 \\
\hline 87 & Other non-electrical machinery & Non-Electrical Equipments & 17 \\
\hline 88 & Electrical industrial Machinery & Electrical \& Electronics Equipments & 18 \\
\hline 89 & Electrical wires \& cables & Electrical \& Electronics Equipments & 18 \\
\hline 90 & Batteries & Electrical \& Electronics Equipments & 18 \\
\hline 91 & Electrical appliances & Electrical \& Electronics Equipments & 18 \\
\hline 92 & Communication equipments & Electrical \& Electronics Equipments & 18 \\
\hline 93 & Other electrical Machinery & Electrical \& Electronics Equipments & 18 \\
\hline 94 & Electronic equipments(incl.TV) & Electrical \& Electronics Equipments & 18 \\
\hline 95 & Ships and boats & Transport \& Transport Equipments & 19 \\
\hline 96 & Rail equipments & Transport \& Transport Equipments & 19 \\
\hline 97 & Motor vehicles & Transport \& Transport Equipments & 19 \\
\hline 98 & Motor cycles and scooters & Transport \& Transport Equipments & 19 \\
\hline 99 & Bicycles, cycle-rickshaw & Transport \& Transport Equipments & 19 \\
\hline 100 & Other transport equipments & Transport \& Transport Equipments & 19 \\
\hline 104 & Aircraft \& spacecraft & Transport \& Transport Equipments & 19 \\
\hline 109 & Railway transport services & Transport \& Transport Equipments & 19 \\
\hline 110 & Land tpt including via pipeline & Transport \& Transport Equipments & 19 \\
\hline 111 & Water transport & Transport \& Transport Equipments & 19 \\
\hline 112 & Air transport & Transport \& Transport Equipments & 19 \\
\hline 113 & Supporting and aux. tpt activities & Transport \& Transport Equipments & 19 \\
\hline 101 & Watches and clocks & Precision Tools & 20 \\
\hline 102 & $\begin{array}{l}\text { Medical, precision \&optical } \\
\text { instruments }\end{array}$ & Precision Tools & 20 \\
\hline 103 & Jems \& jewelry & $\begin{array}{l}\text { Miscellaneous Manufacturing } \\
\text { Products }\end{array}$ & 21 \\
\hline 105 & Miscellaneous manufacturing & $\begin{array}{l}\text { Miscellaneous Manufacturing } \\
\text { Products }\end{array}$ & 21 \\
\hline 106 & Construction & Amenity Infrastructure & 22 \\
\hline 107 & Electricity & Amenity Infrastructure & 22 \\
\hline 108 & Water supply & Amenity Infrastructure & 22 \\
\hline 114 & Storage and warehousing & Amenity Infrastructure & 22 \\
\hline 115 & Communication & Amenity Infrastructure & 22 \\
\hline 116 & Trade & All Services & 23 \\
\hline 117 & Hotels and restaurants & All Services & 23 \\
\hline 118 & Banking & All Services & 23 \\
\hline 119 & Insurance & All Services & 23 \\
\hline 120 & Ownership of dwellings & All Services & 23 \\
\hline 121 & Education and research & All Services & 23 \\
\hline 122 & Medical and health & All Services & 23 \\
\hline 123 & Business services & All Services & 23 \\
\hline 124 & Computer \& related activities & All Services & 23 \\
\hline 125 & Legal services & All Services & 23 \\
\hline
\end{tabular}


Table 11 Aggregation scheme (Continued)

\begin{tabular}{llll}
\hline 126 & Real estate activities & All Services & 23 \\
127 & Renting of machinery \& equipment & All Services & 23 \\
128 & O.com, social \&personal services & All Services & 23 \\
129 & Other services & All Services & 23 \\
130 & Public administration & All Services & 23 \\
\hline
\end{tabular}

\section{Competing interests}

I confirm that none of the authors have any competing interests in the manuscript.

\section{Authors' contributions}

PS carried out the calculation of the study and partial drafting of the article. KM revised the whole article including conclusion. Both authors read and approved the final article.

\section{Acknowledgement}

This work is one of the last compilations of Prof. Debesh Chakraborty (Former Professor, Department of Economics, Jadavpur University, Kolkata) before his sad demise on 22nd May, 2014. His inspiration and guidance saw us through every line of this paper. We dedicate this paper to his heavenly soul. Responsibility for errors, if any, remains entirely to us.

\section{Author details}

${ }^{1}$ Indian Chamber of Commerce, Prakriti Abasan, Flat No: A 32, 343, Garia Gardens, Kolkata 700 084, India. ${ }^{2}$ Department of Natural Resource Sciences, Agricultural Economics Program, McGill University, Macdonald Campus, 21,111 Lakeshore Road, Ste Anne de Bellevue, Montreal, Quebec H9X3V9, Canada.

Received: 3 June 2015 Accepted: 9 February 2016

Published online: 25 February 2016

\section{References}

Bhushan H (2013) National Food Security Act: Work in Progress. Yojana 57(Special Issue):4-7

Brahmanand PS, Kumar A, Ghosh S, Roy Chowdhury S, Singandhupe RB, Singh R, Nanda P, Chakraborthy H, Srivastava SK, Behera MS (2013) Challenges to food security in India. Current Science 104(7):841-846

Chakraborty D, Mukhopadhyay K (2014) Water pollution and Abatement Policy in India: A Study from an Economic Perspective, Springer, the Netherlands., ISBN: 978-94-017-8928-8

Chhibber A (2013) Why India's rampant inflation remains a puzzle? The Economic Times, October 04

CSO (2012) Input Output Transaction Table 2007-08., Central Statistical Organisation, Ministry of Statistics and Programme Implementation, Government of India, New Delhi

Economist (2010) The Millennium Development Goals., The Economist, 25 $5^{\text {th }}$ September: 31-34

FAO (2009) The State of Food insecurity in the World-Economic Crisis Impacts and Lessons Learned, Food and Agriculture Organization of The United Nations Rome, 2009

FAO (2014) Agriculture's greenhouse gas emissions on the rise., Accessed on September 2015 http://www.fao.org/ news/story/en/item/216137/icode/

Ghosh A (1958) Input-Output Approach in an Allocation System. Economica 25(97):58-64

GOI (2013) Department of Food and public distribution, Ministry of Consumer Affairs Food and Public Distribution, NFSA 2013. Accessed on September $2014 \mathrm{http} / / /$ dfpd.nic.in/nfsa-act.htm

Gulati A, Gujra J, Nandakumar T, Jain S, Anand S, Rath S, Joshi P (2012) National Food Security Bill: Challenges and Options, Discussion Paper No. 2, Commission for Agricultural Costs and Prices, Department of Agriculture \& Cooperation, Ministry of Agriculture, Government of India New Delhi December 2012

Kattumuri R (2011) Food Security and the Targeted Public Distribution System in India, LSE Asia Research Working Paper 38. London School of Economics, London

Kaushal N, Muchomba F (2013) How Consumer Price Subsidies Affect Nutrition., National Bureau of Economic Research Working Paper 19404

Kotwal A, Murugkar M, Ramaswamy B (2013) Some reflections on National Food Security Act. Yojana 57:25-29

Krishnamurthy P, Pathania V, Tandon S (2014) Food Price Subsidies and Nutrition: Evidence from State Reforms to India's Public Distribution System, Selected Paper prepared for presentation at the Agricultural \& Applied Economics Association's 2014 AAEA Annual Meeting, Minneapolis, MN, July 27-29, 2014

Leontief WW (1951) The Structure of the American Economy 1919- 1939: An Empirical Application of Equilibrium Analysis. Oxford University Press, New York

Miller RE, Blair PD (2009) Input-Output Analysis, Foundations and Extensions., Second Edition, Cambridge University Press, UK

Mishra P (2013) The Food Security Act (FSA) Fiscal Implications: 2013-14 to 2015-16. Yojana 57:8-12

Parikh KS (2013) Food Security Bill-Would it wipe out Hunger and Malnutrition? Yojana 57:18-21

Planning Commission (2013a) Press Note on Poverty Estimates, 2011-12 Government of India

Planning Commission (2013b) Twelfth Five Year Plan (2012-17), Volume II:18 Government of India

Planning Commission (2013c) Twelfth Plan Working Group on Crop Husbandry, Demand and Supply Projections,

Agricultural Inputs and Agricultural Statistics., Directorate of Agriculture \& Cooperation, Government of India 
Rakshit M (2003) Some Analytics of Medium and Long Term Food Policy. Economic and Political Weekly 38(18): $1777-1794$

Rammohan A (2013) Food Security in India and Food Security Bill. Yojana 57:35-37

Shirur M, Gowda NSS (2014) India's National Food Security Act: Implications on Indian Agriculture. Int J Res Appl, Nat Soc Sci 2(5):247-260

Sinha D (2013) Cost of Implementing the National Food Security Act. Economic \& Political Weekly 48(39):31

Sirkar A (2013) Ektu Beshi Bhat Chaileo Paben Na., Ananda Bazar Patrika

Swaminathan M (2013) Implementing the Food Security Act. Yojana 57:22-24

Tarozzi A (2002) The Indian Public Distribution System as Provider of Food Security: Evidence from Child Anthropometry in Andhra Pradesh., http://www.princeton.edu/rpds/papers/pdfs/tarozzi_indian_public_ distribution_system.pdf. Accessed on 7th September 2015

Tarozzi A (2005) The Indian Public Distribution System as a Provider of Food Security: Evidence from Child Nutrition in Andhra Pradesh. European Economic Review 49:1305-1330

UN (1999) The Right to Adequate Food (Art.11): 12/05/1999.E/C/.12/1999/5, Committee on Economic, Social and Cultural Rights, Twentieth session, Geneva, 26 April-14 May 1999, Agenda item 7, United Nations

WFP (2015) World Food Programme, India., Available at https:/www.wfp.org/countries/india, Accessed on February 2015

World Bank (2010) Poverty in India, http:/wwww.worldlibrary.org/articles/poverty_in_india Accessed on March 2015 WRI (2014) Everything You Need to Know About Agricultural Emissions by Stephen Russell, World Resources Institute Accessed on September 2015 http://www.wri.org/blog/2014/05/everything-you-need-know-about-agriculturalemissions

Submit your manuscript to a SpringerOpen ${ }^{\circ}$ journal and benefit from:

- Convenient online submission

- Rigorous peer review

- Immediate publication on acceptance

- Open access: articles freely available online

- High visibility within the field

Retaining the copyright to your article

Submit your next manuscript at $\gg$ springeropen.com 